\title{
A influência da apocalíptica judaica no relato da transfiguração em $M t$ 17,1-8
}

\author{
Orientador: Geraldo Dondici Vieira \\ Mestrando: Leonardo dos Santos Silveira \\ Área de Concentração: Teologia Bíblica
}

Linha de Pesquisa: Análise e Interpretação de Textos do Antigo e Novo Testamento

A apocalíptica judaica tem um papel importante no cristianismo primitivo, assim como no judaísmo da diáspora. Quando lemos o relato da transfiguração no evangelho de Mateus e comparamos o mesmo com os do evangelho de Marcos e Lucas, percebemos semelhanças e diferenças. Dentre as diferenças, aquelas apresentadas pelo evangelho de Mateus chamam a atenção pelo realce que dá aos aspectos apocalípticos. Por isso, a presente pesquisa analisa a influência da apocalíptica judaica no relato da transfiguração no evangelho de Mateus. Para tanto, a pesquisa começa abordando as questões centrais da apocalíptica judaica e, também o contexto histórico do evangelho de Mateus, ou seja, sua relação com o ambiente romano e com os "Judaísmos" do final do primeiro século d.C. Em seguida, a perícope de Mt 17,1-8 é analisada mediante o método histórico-crítico, que dentre as análises do método, destaca como o redator trabalhou a sua fonte, o relato do evangelho de Marcos. Por fim, os aspectos teológicos da perícope estudada são analisados, tendo como princípio a comparação com textos da apocalíptica judaica que possuem alguma correspondência. A correspondência, em cada ponto, é feita observando a seguinte ordem: cronológica, semântica e teológica. Dessa forma, a pesquisa ratifica a idéia que para se entender o relato de Mateus da transfiguração é necessário o conhecimento da apocalíptica judaica.

Palavras-chave: Apocalíptica Judaica; Cristianismo Primitivo; Evangelho de Mateus. 